\title{
A Modern Support For Training Geodetic Students In Romania
}

\author{
Caius Didulescu \\ Surveying and Cadastre Department \\ Faculty of Geodesy, Technical University of Civil \\ Engineering Bucharest, Romania

\section{Adrian Savu} \\ Surveying and Cadastre Department \\ Faculty of Geodesy, Technical University of Civil \\ Engineering Bucharest, Romania
}

\section{Constantin Coşarcă}

Surveying and Cadastre Department

Faculty of Geodesy, Technical University of Civil Engineering Bucharest, Romania

Aurel Sărăcin

Surveying and Cadastre Department

Faculty of Geodesy, Technical University of Civil

Engineering Bucharest, Romania

\author{
Gheorghe Badea \\ Surveying and Cadastre Department \\ Faculty of Geodesy, Technical University of Civil \\ Engineering Bucharest, Romania
}

\section{Ana Cornelia Badea}

Surveying and Cadastre Department

Faculty of Geodesy, Technical University of Civil

Engineering Bucharest, Romania

\begin{abstract}
Through the e-learning system called "geodesyinstruct”, Technical University of Civil Engineering Bucharest offers its students a modern learning tool in geodetical domain, an online collaboration platform integrated with an e-Learning system, allowing the use of digital course modules, interactive teaching and student centered learning, thus ensuring potential to enhance access and participation in higher education.
\end{abstract}

Keywords- e-learning; internet teaching platform, interactive teaching.

\section{INTRODUCTION}

The main responsibility of the teacher is oriented to design methods and student-centered learning environments, with less emphasis on traditional responsibility to transmit only information.

The relationship between student and teacher is a partnership in which each is responsible to achieve learning outcomes.
These are explained and discussed with students in terms of their relevance for thorough assimilation of knowledge.

There are supervisors or deans of year responding to all requests of students taking touch with them.

The university is continuing self-identification, development, testing, implementation and evaluation of effective learning techniques, including novel applications of computers and information technology. Study programs are integrated with internships and student involvement in research projects.

Teachers communicate with students in teaching activity (through questions in the classroom, short presentations, demonstration experiments) and teaching is guided by the pace and manner of student learning.

Student-centered education becomes, in these circumstances, one of the most important trends guiding teaching in the academic environment. Student-centered learning orientation is revealed by placing learning at the heart of the educational process through increased attention paid to the activities of counseling, orientation and mobility of students, but also by 
the fact that the latter becomes an active partner in the qualitative assessment and shaping their own academic path. Given student-centered learning, student, future expert is no longer seen as a passive subject in education and training, but is considered a partner of the teacher in knowledge construction and active part in implementation of educational activities.

Unlike the practice so far in the university, the teacher put emphasis on teaching knowledge, followed by their evaluation, with minor importance of student learning in terms of student-centered. From the perspective of student-centered education, teaching and learning are two processes that require each other. Teaching is not limited to simple transmission of knowledge. It combines training with the formation and learning with assessment in accord with established finalities.

The teacher renounces to knowledge delivery as a product and focuses on the knowledge as process, giving more attention to the needs of learning, motivation, counseling and guidance of the students. In teacher-centered education by approaching knowledge as product, teachers gave students cognitive finished products, prefabricated stock of truths expressed through knowledge and stimulated exercises and their reproductive capacities.

Student-centered education approaches knowledge as a process, teachers aim to focus on student thinking, on their involvement in projects, on solving problems pertaining to practical life (by finding new solution thereof), on scientific research and learning new research techniques, stimulating thought, imagination, creativity and originality learners and removing the lack of motivation and formalism.

University contributes to student-centered learning, both by providing absolutely necessary institutional conditions for optimum relationship between teacher and student in the educational process in the university environment and by providing materials, resources, programs, services and regulations, adequate to this new approach of education.

Final desideratum is competence. From this perspective, higher education has to provide opportunities for continuous learning and training adapted to the rapid changes in science, technology and the labor market.

This implies a higher education concerned about quality assurance which ensures curricular compatibility that enables skills training ,consistent with those required by the European labor market.

Student-centered education is one of the main points that are at the core of European higher education reform, known as the Bologna Process. University students, teachers of the institution and not least, the institution of higher education contributes to student-centered education. Each of these factors plays a decisive role in building an education focused on student needs, for which the absence or lack of involvement of one of the factors is impossible to achieve student-centered education.

Student-centered education lead to a new type of studies organization, to achieve the design, conduct and evaluation of the university educational activities, in which universities and academics should consider the following items, presented as moments of PDCA cycle (Plan - Do - Check - Act) and integrate autonomously appropriate policies corresponding to the level of development and autonomy of universities.

\section{REFERENCE POINTS CONCERNING ADAPTATION OF}

MATERIALS AND INSTRUMENTS OF TEACHING AND LEARNING

Currently, are known four ways of organizing teaching and learning tools:

1) the transmission of information frontal, from teacher to student, ie collective activity;

2) the transmission of information from student to student, or work groups generally homogeneous, composed by teacher as a specific criterion;

3) the transmission of information from student to student, or work on teams, heterogeneous groups, formed by student preferences for an activity;

4) Individual work independent.

Information and communication technologies have an important supporting role in modifying the content, process and learning outcomes. They are also an important part of the world in which students live and the ability to use these technologies is not optional, but a basic life skill.

Online learning methods that are based on Internet usage and working methods that encourage collaboration, influence learning and teaching methods. Mixed learning approach combines classroom learning techniques or learning without teacher with online learning tools. Using e-mail facilitates real and virtual exchanges between students, regardless of received education and training followed.

The main points of reference for adapting materials and teaching and learning tools are:

- substantiation teaching on the principle of active and interactive learning and evaluation based on capacities and competencies;

- modernization of the educational process of teaching / learning by developing appropriate information and communication technologies;

- the use of new teaching methods that determine an active and interactive participation of students, introduction of various modes of examination and students cooptation on the development of teaching and research portfolios based on given themes;

- adoption of a new vision, at university level, related to teaching, learning and assessment, in which the student becomes an active subject and contribute through action on its own knowledge, training and development, and the teacher shifts the emphasis from the role of information provider on the roles of organizer and leader, counselor and targeted learning situations creator and evaluator and therapist of education;

- concern for the practical training of students and establishment of agreements between universities and various companies for specialized internships by the students; - development of libraries equipped with analog and digital materials to cover as much of the proposed curriculum and access to international databases. 
Hence, information and communication technologies are a very useful tool for:

1) motivate students and teachers;

2) providing authentic models of communication in the target group;

3) providing curriculum content;

4) promoting educational innovation;

5) facilitate the exchange of teaching methods;

6) consolidation of information processing strategies and development of creativity (search / select / process / extract / communicate / show / etc.).

Education reform was intended to be a comprehensive reform, comprehensive education, conceived as a set of six chapters of measures as follows:

- Curricular reform (curriculum, programs) and European compatibility of the national curriculum;

- The transition from reproductive to the creative learning through problem solving and relaunch research at universities;

- new connection between universities on the one hand, their economic, administrative and cultural environment on the other hand;

- Improve infrastructure and connect to the current world of electronic communications

- Reform of academic management through decentralization and the creation of institutional autonomy of schools;

- Initiate advanced forms of international cooperation.

One of the essential components of comprehensive reform is the curriculum reform of Romanian education, which refers to rethink educational plans and programs at European compatibility of the national curriculum, the integration of learning experiences and training in order to facilitate the development of cognitive complex structures.

National Curriculum in Romania is developed in relation to three basic parts:

1 - dynamics of the Romanian educational system, ie current and future needs of its;

2 - the current trends and generally accepted international curricular reforms;

3 - Romanian educational traditions which correspond in terms of curricular reform.

In the context of increasing internationalization of teaching, teachers and students have to ensure success of specific activities. It should provide flexibility for easy adaptation to specific needs.

It aims to:

- Adapting curriculum to ensure defining career skills in line with labor market needs, priorities arising from the integration in the European Union;

- strengthening existing specializations and identify possible new specializations in the faculty;

- Continuous improvement of quality courses taught by updating information;

- Increasing the practical features on seminars, projects and laboratory classes;

- Reconsideration of practical work in order to make it through proper organization and ensure content meets the requirements of industry;
- Stimulating the interest of students for individual study and research work;

- Development of infrastructure for normal teaching activity;

- Modernization of teaching and assessment system;

- Stimulate development and pedagogical training of teachers;

- Expanding concern for inviting foreign academics and industry experts to expose some very topical issues to students and teachers;

- Providing support for teaching subjects in the curriculum (courses, guides, summaries, etc.).

- Organizing postgraduate courses covering advanced training needs of industrial companies;

- Development of doctoral schools;

An important step is the introduction of computerized online teaching forms. Teaching may be accompanied by a systematic process of evaluation of subjects by students and teachers who support them.

\section{ONLINE SYSTEM - A SOLUTION TO STUDENT-CENTERED INTERACTIVE TEACHING}

At the Technical University of Civil Engineering Bucharest was successfully implemented an e-Learning software solution for online collaborative platform, designed to help increase quality educational offer of technical geodetic education in the following regions: Bucharest-Ilfov region, North-East, Central and West (Fig 1).

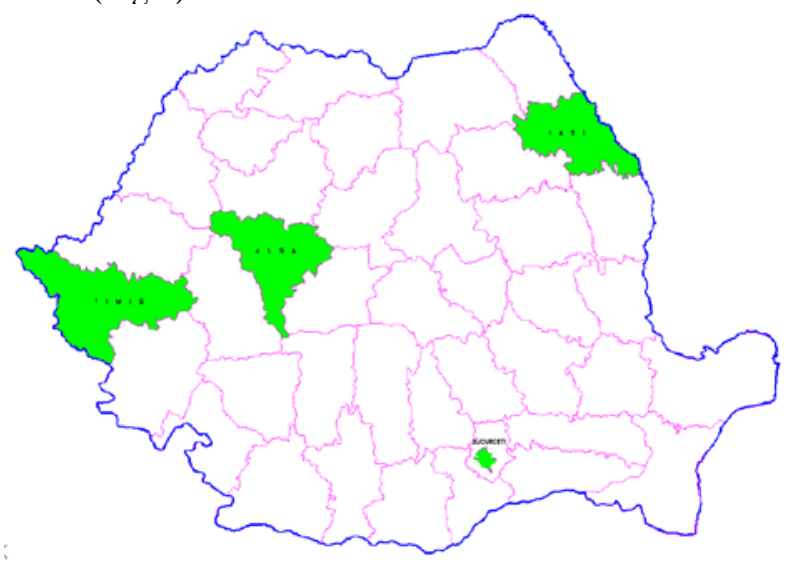

Fig. 1. The regions: Bucharest-Ilfov, North-East, Centre and West of Romania with university centers that collaborate within online platform

This modern way of learning has been implemented in four universities in Romania, in order to restructure the higher education geodetic system by focusing on student learning activities. Students do not have to memorize huge amounts of information, because they are useless if they are treated in an alert manner, unstructured, illogical and without connections and examples of practical application.

New education methods involve experiential learning based on scenarios and alternatives and direct interaction between student learning object and learning environment. In this context the Technical University of Civil Engineering Bucharest wants to raise the standards for educational activities and improve education for "Land Measurements and Cadastre" specialization and its correlation with the labor market. 
Romanian society developments in conjunction with integration into the European Union made the right property to become a fundamental part of the economy and people's lives in general. Real estate situation in our country is still a sensitive issue, although great efforts were made in developing legislation to clarify the situation created by the communist regime.

Technical issues facing professionals are: overlapping boundaries of properties, corners with incorrect coordinates, structuring information about property and charging them in the system, difficulties with legal component of restitution and possible retrieval of the original locations .

The problem of preparation of graduates who can solve complex and diverse issues is urgently needed, both to clarify various situations, guaranteeing property rights and development of a robust real estate market in the European context.

Thus, the existence of harmonized and standardized training program at multiregional level, allows adapting curriculum content to the requirements of global markets and ensure a much wider opening skills that students will acquire at the end of training.

Standards of Quality Assurance in Higher Education require continuous improvement of educational technologies and processes for practice and assessment of skills acquired by students. In this sense, the project covers the requirements imposed by the labor standards. Computer-aided technology offers opportunities to increase efficiency and effectiveness in higher education.

Integrated IT solution carried out in the project supports the steps of Technical University of Civil Engineering Bucharest to strengthen the current relationships to multi-regional level between universities, business and research centers.

Advantages from the point of view of the student, against the classical training, are that it does not depend on a precise location or a particular imposed program of study and the accumulation of knowledge is determined by student depending on his physical or intellectual availability.

Other advantages are:

- belonging to a community interested in the subject or discipline,

- Capacity to work in collaboration (highly valued by employers)

- develop new skills and abilities through the use of information and communication technologies.

From the point of view of the applicant institution, the advantages of implementing the project are:

- considerable reduction of material involved;

- number of students does not depend on physical space available;

- reduce costs of teaching materials and interior equipment maintenance costs.

The system contributes to the increase of people who have a stable and sustainable employment because of their online learning activities. In this way a higher level of qualification is achieved by Bachelor graduates who live in other cities than university centres and contribute to additional activities that could not be funded from other sources in the near future.

The purpose of the technical network in the Romanian geodetic higher education in the four regions is to improve the quality of curricula and provided qualifications, increasing relevance in relation to the market labor. Thus the four universities have formed a joint working team and developed a specific standard specializations on which a common curriculum has been developed.

The project has a innovative part by the fact that the revised training package was digitized, thus creating a library of virtual resources that can be accessed by students remotely via the Internet. Digital materials not practice memorizing ability of the student (phenomenon, process, concept), assimilation is the result of experiments on a set of possible solutions and analysis of results obtained in each case.

"Students always tell us that a good teacher is one who makes harder things seem to you easier. Geodesy-Instruct project gave them the ideal teacher. Now, that the academic year is about to begin, the project can finally take a vacation. Platform works. "- Professor Johan Neuner, Rector of the Technical University of Civil Engineering Bucharest, at the closing conference of the project in September 2012.

\section{CONCLUSION}

Access to digital (online) learning resources contribute to attracting and motivating valuable young people, their adaptation to present conditions and future market labor. It will improve the training of future researchers for several areas critical to the national economy.

Are highlighted training requirements to meet internal labor market requirements, so that future engineers to be able to integrate specific training activities, where they find the most favorable opportunities.

The university is continuing self-identification, development, testing, implementation and evaluation of effective learning techniques, including novel applications of computers and information technology.

\section{PERSPECTIVES}

From the desire to improve the students access to learning and research (on-line) resources, it is intended to achieve a project involving modernization of teaching process with an online platform for Masters Degrees.

\section{REFERENCES}

[1] www.geodesy-instruct.ro

[2] The Romanian Agency for Quality Assurance in Higher Education, "Independent evaluation report of ARACIS activity during piloting the implementation methodology for external evaluation of quality assurance in higher education”, București, 2007; ARACIS, "Raport independent de evaluare a activității ARACIS în perioada de pilotare a aplicării Metodologiei de evaluare externă a asigurării calității în învățământul superior.”,Bucureşti, 2007

[3] Mihai KORKA "et. al", "Quality education to the labor market"; "Educație de calitate pentru piața muncii”, Editura Universitară Bucuresti,

[4] Vasile Valentina "et. al"., "Restructuring the education system in Romania in terms of domestic developments and their impact on research progress"; "Restructurarea sistemului de educație din România din perspectiva evoluțiilor pe piața internă şi impactul asupra progresului cercetării”, Bucureşti, Apha Media Print, 2008.

\section{Creative Commons Attribution License 4.0 (Attribution 4.0 International, CC BY 4.0)}

This article is published under the terms of the Creative Commons Attribution License 4.0 https://creativecommons.org/licenses/by/4.0/deed.en US 